\title{
Cases of Shattered Dreams: Justice Samuel Freeman Miller and the Rise and Fall of a Mississippi River Town
}

\author{
Michael A. Ross
}

UNITED STATES SUPREME COURT JUSTICE Samuel Freeman Miller sat on the nation's highest court for twentyeight years. When he looked at the judiciary and other branches of the federal government during the Gilded Age, he did not like what he saw. Once sanguine about the prospects for the American economy and democracy, he grew increasingly pessimistic. The American government, Miller wrote in 1878, had been subverted by a "keensighted well organized class" of selfish men who manipulated the judicial and legislative branches for their own ends. "I have met with but few things," he added, "of a character affecting the public good of the whole country that has shaken my faith in human nature as much as the united, vigorous and selfish efforts of the capitalists. ${ }^{\prime 1}$ In his judicial opinions and private correspondence, Miller repeatedly revealed that the growth of a powerful capitalist class after the Civil War had destroyed his once strong faith in the American economic system.

\footnotetext{
I would like to thank Douglas Atterberg, William Barney, Marvin Bergman, Peter Coclanis, Roger Lotchin, and Timothy Mahoney for their assistance in the preparation of this article. I also gratefully acknowledge that a Sesquicentennial Research Grant helped to fund the research.

1. Miller to William Pitt Ballinger, 28 April 1878, folder 3, box 2, Samuel Freeman Miller Papers, Library of Congress, Washington, DC.
}

THE ANNALS OF IOWA 57 (Summer 1998). CThe State Historical Society of Iowa, 1998. 


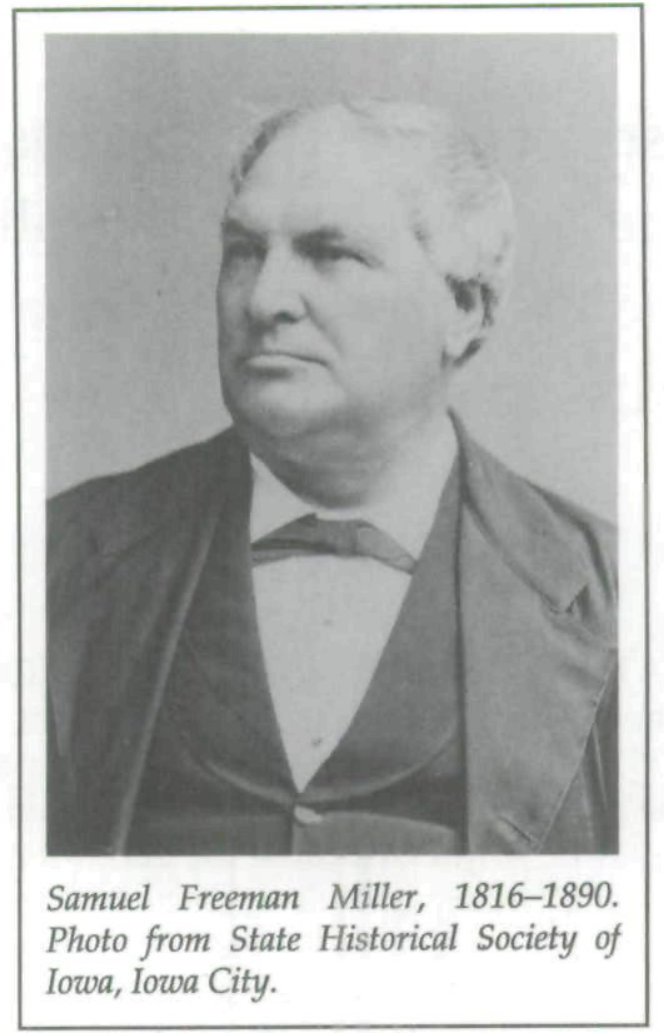

Some historians have argued that Miller's bitter critique of capitalism stemmed from "agrarian radicalism," and that his judicial, political, and economic views reflected the keen anger that farmers in his home state of Iowa felt for railroads, financiers, and city dwellers. Miller, in this view, was a nascent populist whose Jeffersonian love of the yeoman farmer, agricultural America, and the rich soil of Iowa led him to question the new urban, industrial, capitalist order. ${ }^{2}$ This flawed assessment of Miller is based on the overly simplistic view that being from Iowa meant that Miller shared farmers' agricultural values. In

2. See, for example, Charles Fairman, Mr. Justice Miller and the Supreme Court, 1862-1890 (New York, 1939), 299; G. Edward White, The American Judicial Tradition: Profiles of Leading American Judges (New York, 1976), 86; Lawrence M. Friedman, A History of American Law (New York, 1973), 331; Leon Friedman and Fred Israel, eds., The Justices of the United States Supreme Court, 17891969,5 vols. (New York, 1969), 2:1023. 
fact, Miller's critique of capitalism had little to do with agrarianism. Instead, he shared the values of those Iowans who settled in Mississippi River towns in the 1850s and who hoped that those towns would grow into major cities. To understand Samuel Miller, a man most legal historians agree was one of the great judicial minds of his day, one must understand his participation in the dramatic rise and traumatic collapse of those river town dreams. In Keokuk, Iowa, he experienced both the exhilaration of a frontier boom town and the terrible economic calamity that struck that town on the eve of the Civil War.

IN THE 1850s, Miller and many other Keokuk residents believed that their new town would soon become one of the great cities, if not the great city, of the West. Dubbing Keokuk the "Gate City" of Iowa, they predicted that this "infant Hercules" would someday eclipse both Chicago and St. Louis. Immigrants and men of capital, the town's supporters argued, would soon bypass other better-known cities in favor of Keokuk. "The majestic Mississippi will bear the trophies of the advance of Keokuk in every boat that passes St. Louis," one guidebook forecasted, "whilst Chicago will strive in vain to recall her truant merchants who have realized the advantages of Keokuk." Though it is tempting to discount these claims as hyperbole and overblown boosterism, Keokuk's promoters could indeed point to an impressive array of natural advantages and recent economic achievements that suggested a bright future for the town. ${ }^{3}$

At a time when steamboats served as the primary means of access to the Great West, Keokuk held an enviable location at

3. Keokuk Gate City (hereafter Gate City), 11 March 1856; William Rees, Description of the City of Keokuk, Lee Co., Iowa (Keokuk, 1855), 20, 22. More than sheer hucksterism, the booster ethos reflected a genuine optimism about the effects of economic expansion. The best discussion of boosters of Mississippi River towns is in Timothy Mahoney, River Towns of the Great West: The Structure of Provincial Urbanization in the American Midwest, 1820-1870 (New York, 1990). See also Carl Abbott, Boosters and Businessmen: Popular Economic Thought and Urban Growth in the Antebellum Middle West (Westport, CT, 1981), 126, 129, 207; William Cronon, Nature's Metropolis: Chicago and the Great West (New York, 1991), 9, 35, 47; Jeffrey S. Adler, Yankee Merchants and the Making of the Urban West: The Rise and Fall of Antebellum St. Louis (New York, 1991), 43. 
the confluence of the Mississippi and Des Moines Rivers. As the first Iowa city encountered by travelers up the Mississippi, Keokuk served as the entryway to one of the most fertile regions on the globe. And, sitting at the base of the Des Moines River Valley, Keokuk was positioned to control the trade of an area that contained half of Iowa's population and agricultural wealth. In stark contrast to the sleepy subsistence homesteads that surrounded Samuel Miller's previous home in Barbourville, Kentucky, the fecund countryside around Keokuk had filled with prolific cash-crop farms. Iowa's settlers were preoccupied with economic success and access to markets. As the most convenient trading depot for this productive region, Keokuk enjoyed a prime location. ${ }^{4}$

By the time Miller arrived in the spring of 1850, Keokuk had grown from a rustic trading village with a few rickety cabins into a rising entrepôt with dozens of dry goods stores, harness shops, blacksmiths, coopers, and other businesses. Because all the river traffic heading north from New Orleans or St. Louis had to stop at Keokuk to transport goods past the infamous stretch of river rapids located there, the Gate City's boosters could rightly claim that the rapids made their town an economic necessity. And because steamboats had to be unloaded at Keokuk, the town also became the natural transshipment point for goods being sent to Iowa's interior towns. On summer days in the early 1850 s, Keokuk's levee and waterfront streets were crowded with hundreds of carts and covered wagons full of merchandise destined for Des Moines, Winterset, Ottumwa, and other points west. The wagons of inland farmers and merchants were joined by bands of westward emigrants who used Keokuk as their "jumping off point." Bound for the gold fields of California or the Mormon settlements on the Great Salt Lake, these travelers arrived by steamboat and camped in Keokuk while they outfitted themselves for their

4. Robert P. Swierenga, Pioneers and Profits: Land Speculation on the Iowa Frontier (Ames, 1968), 21; Allan Bogue, From Prairie to Corn Belt: Farming on the Illinois and Iowa Prairies in the Nineteenth Century (Chicago, 1963); Faye Erma Harris, "A Frontier Community: The Economic, Social, and Political Development of Keokuk, Iowa, from 1820 to 1866 " (Ph.D. diss., University of Iowa, 1965), 185; Mahoney, River Towns, 51, 52, 84. 
westward journey. Mormon encampments could resemble small cities. In 1853, for example, "some 3500 souls-besides wagons, cattle, tents and animals numberless" camped outside of town.

Many emigrants, entranced by Keokuk's boomtown atmosphere, simply stopped and stayed. Brick and wood frame houses sprouted everywhere. Hundreds of tents sheltered the overflow. "I am acquainted with no other town on the Mississippi River growing more rapidly than Keokuk," noted a visitor in 1848. The pace of growth accelerated in the early 1850s, and the Keokuk Post predicted in 1855 that "Keokuk will double its population, wealth and importance in the coming year." At mid-decade, buildings under construction were the city's most prominent feature. Many of Keokuk's streets were "almost completely blocked with great piles of brick, sand, lumber, lime and mortar beds." "All the dwelling houses are occupied," one Keokuk citizen declared, "and the cry is still for more." ${ }^{\prime 6}$

By modern standards, a city of fifteen thousand hardly amounts to a major metropolis. But that figure, standing alone, fails to reflect the constant bustle, astonishing growth, and hard-charging attitude in Keokuk and its hinterland. Farmer and merchant alike possessed an aggressive economic outlook. The farmers, responsive to market demands, gravitated to producing corn and hogs on a prodigious scale. Gate City merchants and entrepreneurs had an equally vigorous commercial spirit. When the opportunities arose, they aggressively expanded the size, scale, and scope of their establishments. Merchants and farmers shared an ethos of hard work and economic optimism. As one Keokuk resident wrote in 1853, "No rich man emigrates to the West and those that are rich have made this money by hard work. 'Every man for himself' is the

5. Mahoney, River Towns, 145-48; Robert Conner, "A River History of Keokuk," unpublished manuscript, 1950, State Historical Society of Iowa, Iowa City; Harris, "Frontier Community," 85; History of Lee County, Iowa (Chicago, 1879), 624-25; William Worth Belknap to Clara Belknap, 3 May 1853, William Worth Belknap Papers, Special Collections and Manuscripts, Princeton University Library, Princeton, NJ.

6. Keokuk Register, 20 July 1848; History of Lee County, 624; Keokuk Daily Post, 16 December 1855; R. M. Reynolds to C. Throop, 27 May 1856, R. M. Reynolds Collection, State Historical Society of Iowa, Iowa City. 
motto which adorns the armor of each one of us and no coat of arms ever bore a more truthfully correct or more significant emblem." ${ }^{\prime 7}$

The rapid growth of the wholesale business led many Keokuk citizens to believe that their town could soon become an entrepôt on the scale of St. Louis and Chicago. Once dependent on St. Louis for their goods, many Keokuk merchants now ordered their supplies directly from New York. Instead of viewing their town as an important spoke in St. Louis's economic wheel, Keokuk's boosters came to see that city as a competitor. Thanks to growth that "dazzles and bewilders the imagination," Mayor Samuel Curtis exclaimed in 1856, Keokuk would soon acquire "wealth and grandeur that may hereafter rival ... the great cities of ancient and modern times."

Not content to rest on their laurels, Keokuk's builders and elected officials strove to provide the town with amenities normally reserved for larger or more established cities. They built theaters and schools and sold city bonds to pay for the construction of a medical college. They graded the roads and installed gas-lit street lamps. They planned a sophisticated waterworks. Comfortable homes and regal churches filled the side streets. Determined that Keokuk should have a first-class hotel, developers began work on the grand, multistoried Estes House.

One can imagine how impressive Keokuk must have appeared to steamboat passengers arriving at the city's docks in the 1850s. After a long, two-hundred-mile trip from St. Louis, the Gate City must have seemed a frontier oasis, with hundreds of restaurants, theaters, saloons, shops, hotels, and success stories, a gas-lit jewel glimmering on the bluffs overlooking the Mississippi.

7. William Worth Belknap to Clara Belknap, 17 March 1853, Belknap Papers.

8. Cronon, Nature's Metropolis, 62; "Inaugural Address of Mayor Curtis," 9 May 1856, reprinted in Orion Clemens, City of Keokuk in 1856 (Keokuk, 1856), 4; Gate City, 4 May 1861. See also Lewis Atherton, The Frontier Merchant in Mid-America (Columbia, MO, 1971); James E. Vance Jr., The Merchant's World: The Geography of Wholesaling (Englewood Cliffs, NJ, 1970); Mahoney, River Towns, 211-13, 272.

9. Clemens, City of Keokuk, 8; History of Lee County, 623. 


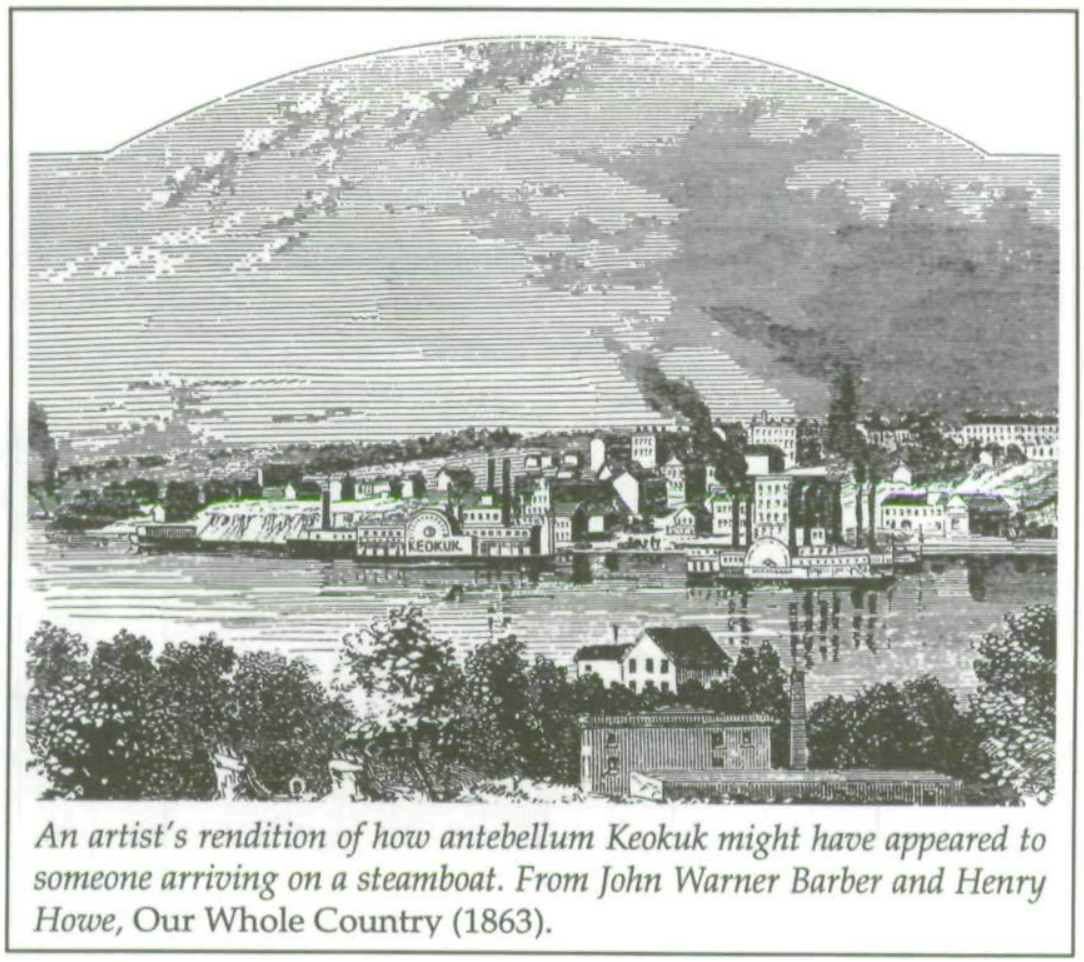

SAMUEL MILLER had settled in Keokuk in 1850 after leaving behind another town that boosters had hoped would grow into a great metropolis. Born in Kentucky, Miller spent his early career first as a doctor, then as a lawyer, in the small southeastern Kentucky hill town of Barbourville, a hamlet some residents predicted would grow into a great "western gate to the frontier." Located near the Old Wilderness Road on the Kentucky side of the Cumberland Gap, Barbourville served as a trading town for westward emigrants. Although the town prospered during the great overland migrations of the early 1840 s, its economy had profound structural weaknesses. The hardscrabble farms that surrounded the town were cursed with poor soil and limited access to broader markets, and the subsistence farmers who tended them seldom patronized the town's merchants. Without an economic hinterland, the merchants depended solely on the emigrant trade, which eventually proved fatal as steamboats and railroads increasingly stole 
the emigrant traffic from the Old Wilderness Road during the 1840s. As the Old Wilderness Road died, Barbourville dwindled into an economic and political backwater. ${ }^{10}$

By the late 1840s, Miller and other elites in Barbourville were painfully aware of the decline. Miller placed his last hopes for the town on the economic program proposed by Kentucky politician Cassius Clay. Clay wanted Kentucky to follow the example of New England: to rid itself of slavery, to produce diverse foodstuffs, and to build factories. Miller hoped that mills and factories would sprout along the Cumberland River and bring workers and prosperity to his declining community. When Kentucky's powerful slaveowners thwarted Clay's efforts, however, Miller and his family joined the exodus of Barbourville's professional and merchant class to towns in the West. Miller chose to move his family and career to Keokuk, which was thriving because of the same transportation innovation that had doomed Barbourville: steamboats. ${ }^{11}$

During its boom years, Keokuk became a magnet for talented men and women such as Miller. A number of those settlers later achieved national prominence. Among them was Samuel Clemens, who came to work at his brother Orion's printing office in the 1850s. A gifted collection of lawyers also coalesced in the Gate City. Many later became federal cabinet members, influential politicians, judges, and Civil War heroes. George McCrary was elected to Congress and later became Rutherford B. Hayes's secretary of war. John Noble served as secretary of the interior in the Harrison administration. Ulysses S. Grant appointed Keokuk's George Williams attorney general and William Worth Belknap secretary of war. Obviously, Keokuk in the 1850s had a rigorous legal environment. Despite the high level of competition, Samuel Miller moved to the front of this talented field with astonishing speed. ${ }^{12}$

10. Michael A. Ross, "Hill Country Doctor: The Early Life and Career of Supreme Court Justice Samuel F. Miller in Kentucky, 1816-1849," Filson Club History Quarterly 71 (1997), 430-62.

11. Ibid.

12. Samuel Clemens lived in Keokuk during the boom years of 1854-1856. Charles Neider, ed., The Autobiography of Mark Twain (New York, 1959), 94, 95; R. Kent Rasmussen, Mark Twain A to Z: The Essential Reference to His Life and Writings (New York, 1996), 269-70; Fairman, Mr. Justice Miller, 21-22. 
When the thirty-four-year-old Miller arrived with his family in Keokuk in May 1850, he quickly found Lewis Reeves, a successful lawyer in town who happened to be looking for a partner. Despite being a regular at the gambling tables of Keokuk's saloons, Reeves had built an active and lucrative legal practice. He took an immediate liking to the bright and affable Miller, and the two joined forces that summer. Rather than rebuilding his career in Keokuk from the ground up, Miller found himself almost instantly immersed in a demanding and remunerative legal practice. ${ }^{13}$

Much of Reeves and Miller's practice involved real estate disputes. Frontier boomtowns were notoriously tricky places to secure sound land titles, and Keokuk's situation was worse than most. The town sat on a piece of land known as the "Half-Breed Tract," 120,000 acres originally set aside by treaty "for the use of half-breeds belonging to the Sac and Fox nations." Because there were relatively few so-called half-breeds, however, white families soon overran the sparsely settled tract, established farms, and declared ownership. Despite the best efforts of the frontier judicial system to establish who, in fact, held legitimate titles, Keokuk quickly descended into a confusing welter of conflicting land claims that would plague the city throughout the $1840 \mathrm{~s}$ and $1850 \mathrm{~s} .{ }^{14}$ At times, disputes over this land even erupted into mob actions. ${ }^{15}$ But for attorneys the "Half-Breed Tract" was a boon because "every parcel of land, every 'corner' lot, and every other lot was good for a law

13. Samuel Freeman Miller, Autobiography, Caleb Forbes Davis Memoranda, microfilm, reel 2, book 5, pp. 18-19, State Historical Society of Iowa, Iowa City. Reeves's reputation as a gambler is described in a letter from James L. Estes to Charles Mason, 15 December 1853, Charles Mason Papers, State Historical Society of Iowa, Des Moines.

14. The treaty that created the Half-Breed Tract is recorded in 7 Statutes at Large 229. On June 30, 1834, Congress passed an act relinquishing all right and title of the United States to the Half-Breed Tract, and vested title in the so-called half-breeds (4 Statutes at Large 720). A good description of the history of the Half-Breed Tract can be found in Coy v. Mason, the U.S. Supreme Court decision that attempted to permanently settle this difficult issue (58 U.S. [17 Howard] 697 [1855]).

15. James L. Estes to Charles Mason, 6 September 1853, Charles Mason Papers. 
suit. ${ }^{16}$ Within a year, Miller had made enough money to move his family into an impressive house at the corner of Third and High Streets near the center of town. ${ }^{17}$

A double dose of personal tragedy, however, soon overshadowed Miller's career success. First, in 1854, a resurgence of the Asiatic cholera that had so terrorized the nation in 1849 killed Lewis Reeves, leaving Miller to run their large practice on his own. Then, in November of the same year, Miller's wife, Lucy, died of consumption, leaving him a single father with three children. ${ }^{18}$

Despite these setbacks, Miller continued to pursue a fullthrottle legal career. For a time after Reeves's death, Miller worked as a solo practitioner, and he soon became the most sought-after attorney in Keokuk. He also appeared regularly before the state's highest court. In 1855, for example, he was the lead attorney in 15 of the 24 cases Keokuk lawyers argued before the Iowa State Supreme Court. ${ }^{19}$ His practice branched out into virtually all facets of Keokuk life. He handled divorces, contested wills, personal injuries, disputes between

16. Christian Times, 22 July 1862, reprinted in the Gate City, 12 August 1862. The Iowa Reports contain a number of examples of Half-Breed Tract litigation the firm of Reeves \& Miller was involved in. See Rowan v. Lamb, 4 Iowa 468 (1854); Marshall v. McLean, 3 Iowa 363 (1852); Tiffany v. Glover, 3 Iowa 387 (1852); Walker v. Stannis, 3 Iowa 440 (1852); and Wright v. Meek, 3 Iowa 472 (1852).

17. Douglas Atterberg, Samuel Freeman Miller: A Home in Keokuk, A Place in History (Keokuk, 1990), 10. Miller's early career did suffer one small setback. In 1852 he was an unsuccessful candidate for mayor of Keokuk.

18. Miller, Autobiography, reel 2, book 5, pp. 20-21; Fairman, Mr. Justice Miller, 19.

19. In terms of the number of cases argued before the state supreme court, Miller's closest competitor in Keokuk was the firm of Edwards \& Turner, who handled seven cases. The fifteen cases Miller argued before the state supreme court in 1855 were Claggett v. Gray, 1 Iowa 19 (1855); Hinds v. Hinds, 1 Iowa 36 (1855); Farner v. Turner, 1 Iowa 53 (1855); Cox v. Burns \& Rentgen, 1 I.R. 64 (1855); Houston v. Walcott \& Co., 1 Iowa 86 (1855); Stowers v. Milledge, 1 Iowa 150 (1855); Hyde v. Woolfolk and Bacon, 1 Iowa 159 (1855); Young v. Wolcott, 1 Iowa 174 (1855); Mathews v. Gilliss, 1 Iowa 242 (1855); Harkins v. Edwards \& Turner, 1 Iowa 296 (1855); Pipe v. Bateman, 1 Iowa 369 (1855); Oswald \& Company v. Broderick \& Co., 1 Iowa 380 (1855); Death v. Bank of Pittsburgh, 1 Iowa 382 (1855); Wickersham v. Reeves \& Miller, 1 Iowa 413 (1855); Harkins v. Edwards \& Turner, 1 Iowa 426 (1855). 
merchants, bankruptcies, and even criminal cases. Miller's allconsuming career took its toll on his parenting, however. In 1855 he sent his children to live temporarily with their uncle, William Pitt Ballinger, in Galveston, Texas. In the meantime, he rebuilt his life. In 1856 he remarried to Eliza Reeves, his former law partner's widow. He also founded a new law firm with John Rankin, a prominent Republican lawyer in town. ${ }^{20}$

The combination of Miller's career success, his marriage to Eliza, and his own real estate speculations left him relatively well off and destined to become very rich if Keokuk's economic boom continued. Eliza brought to their marriage real estate holdings worth an estimated forty thousand dollars. Samuel's own properties in and around Keokuk were worth about fifty thousand dollars. The couple owned several buildings in Keokuk's business district and a number of undeveloped lots on the outskirts of Keokuk and in the surrounding townships. Samuel also invested in a coal company that mined coal fields north on the Des Moines River and in the railroad line that would bring the coal to town. If, as he expected, Keokuk grew into a metropolis with hundreds of thousands of citizens, he was poised to become a very rich man. His landholdings were directly in the path of future development, and he held stock in the coal and railroad companies that would provide energy and transportation for the developing city. ${ }^{21}$

Miller's speculations in real estate, railroads, and coal mining were part of a much broader speculative craze that swept over Keokuk during its boom years. In the mid-1850s, it seemed that anyone who could afford to was investing in land in and around Keokuk, since growth seemed certain, profits sure. Even ministers and preachers who counseled their parishioners to "lay up ye treasures in heaven" got in on the

20. Miller to William Pitt Ballinger, 7 June 1855, folder 1, box 1, Miller Papers; Atterberg, Samuel Freeman Miller, 21.

21. Douglas Atterberg of the Lee County Historical Society has searched the land records of Lee County and prepared a comprehensive map of Miller's many property holdings. The map is in the society's collection. For a summary, see Atterberg, Samuel Freeman Miller, 26, 27. 
speculative act. The pastor of Keokuk's New School Presbyterian Church owned an entire city block. ${ }^{22}$

AT MID-DECADE Keokuk continued to thrive, but there were hints of dangers ahead. The most apparent was the threat posed by Burlington, Keokuk's primary economic rival in Iowa. The two river towns had been locked in a fierce competition during the early 1850 s for control of southern Iowa's farm and steamboat trade. Each town hoped, at the very least, to secure the role of secondary entrepôt north of St. Louis. ${ }^{23}$ During the early 1850s, Keokuk appeared to be slightly ahead in this close race for regional dominance. A key turning point in the rivalry came, however, in 1856, when Burlington became the first of the two cities to be reached by a railroad.

The arrival of the Chicago, Burlington and Quincy Railroad $(C B \& Q)$ gave Burlington a powerful advantage over Keokuk. Farmers who traded in Burlington now could compare crop prices in two markets, either the traditional outlet at St. Louis or the newly accessible Chicago. Within a short time, the railroads captured a large portion of the Mississippi River traffic. Wheat and flour, in particular, gravitated to the higher prices paid at the Chicago market, a trend that did not go unnoticed in Keokuk. Initially, the Keokuk papers tried to downplay the importance of Burlington's railroad connection. A "ricketty [sic] branch of a Railroad has been constructed into the swamps opposite Burlington," announced one editor, adding that the terminus would be under water half the year. But such dismissals soon turned to grave concern that "a very considerable section of trade . . . has been drawn . . . to Burlington, on account of her ... railroad facilities. ${ }^{24}$

Railroads also gave Burlington's merchants an advantage. They now could purchase their goods at the great Chicago

22. Rees, Description of the City of Keokuk, 22; M. L. Townsend, "Liberal Religion in Iowa," unpublished manuscript, 1930, State Historical Society of Iowa, Iowa City.

23. Mahoney, River Towns, 273.

24. Ibid., 191; quote of a Keokuk editor reprinted in the Iowa State Gazette (Burlington), 4 April 1855; Gate City, 19 February 1858. 
wholesale houses. Inventories could even be acquired during the winter, when ice on the river shut down the steamboat trade. Keokuk also quickly became a communications backwater. The railroad brought to Burlington dependable mail service as well as the telegraph lines that soon paralleled the CB\&Q tracks. While Keokuk often had no mail for two or three days, Burlington now had the telegraph and two daily mail runs from Chicago. ${ }^{25}$

Keokuk's leaders clearly recognized the importance of railroads and the way they had changed the economic landscape. "Railroads wield the power of men and cities," Keokuk's Mayor Samuel Curtis stated. "They command, and commerce obeys. They can create and destroy, restrain and enlarge.... Without Railroads, Keokuk would sicken and dwindle down to a local village. ${ }^{26}$ Samuel Miller also comprehended Keokuk's need for a railroad. In Barbourville he had already seen what could happen to a town when transportation innovations passed it by. As early as 1852, Miller had advocated building railroads for Keokuk and had joined resolutions "in favor of an appropriation by Congress of land for the construction of these works." ${ }^{27}$

A direct railroad connection with the East held particular importance for Keokuk's grand aspirations. It was, after all, the great New York-to-Chicago trunk lines that had confirmed Chicago's dominant economic position. If Keokuk had any hope of matching the success of Chicago or St. Louis, it needed its own eastern route. ${ }^{28}$ City leaders envisioned an elaborate four-spoked rail system with Keokuk as hub. One line would head north, paralleling the Mississippi to Burlington, another

25. Cronon, Nature's Metropolis, 74; Gate City, 6 January and 12 March 1860. "If we receive one weekly while the river is closed," William Belknap said of Keokuk's winter mail deliveries in 1852, "we consider ourselves doing very well indeed." William W. Belknap to Clara Belknap, 18 January 1852, Belknap Papers.

26. "Inaugural Address of Mayor Curtis," 12.

27. Des Moines Valley Whig (Keokuk), 29 January and 24 June 1852; Fairman, Mr. Justice Miller, 26.

28. "Inaugural Address of Mayor Taylor," reprinted in Orion Clemens, Keokuk Directory and Business Mirror for the Year 1857 (Keokuk, 1857), 145-46. 


\section{THE ANNALS OF IOWA}

would run south to St. Louis, and yet another would traverse the fertile Des Moines River Valley to the state capital and then on to Minnesota. The fourth and most important spoke would be the coveted eastern connection.

But who would pay for this grand scheme? Lack of capital presented an obvious hurdle. Eastern and European capitalists had numerous western suitors hoping to lure them to invest in railroad projects. Recognizing the importance of railroads to economic growth, city officials throughout the West soon came to the fateful conclusion that public monies could and should be used to lure and assist private railroad projects. The vehicle most towns and counties settled on for funding their railroad projects was the issuance of municipal bonds. Towns typically sold these bonds to investors and guaranteed them a solid rate of interest, usually around 8 percent. They would then invest this money in private railroad companies that promised to build a line to their locale. In return, the towns often received company stock. Expecting that the railroads would prosper, town leaders then planned to use the profits from the increasing value of their railroad stock to pay the interest owed to the bondholders. Rosy projections for the railroads' success helped mask the real possibility that the railroads might not be profitable (or worse, never be completed). If that happened, the taxpayers would have to shell out the cash to pay off the bondholders. ${ }^{29}$

Initially, there were some doubts about the legality of using municipal bonds to finance private corporations. Iowa's state constitution prohibited the state from becoming a stockholder in any corporation or from incurring indebtedness over one hundred thousand dollars. It was not clear, however, whether those prohibitions applied to counties and cities as well. In addition, for their authority to issue the bonds, municipalities relied on section 114 of the Iowa Code, which said that with voter approval local governments could provide "aid to construct, any road or bridge which may call for an extraordinary expenditure." Did railroads constitute a "road?" It seemed

29. Charles Fairman, Reconstruction and Reunion, 1864-88, Part 1, History of the Supreme Court of the United States (New York, 1971), 934. 
doubtful given that the legislature had rejected a version of section 114 that would have authorized local government aid for "internal improvements." ${ }^{130}$

In 1853 the Iowa supreme court, in a brief but sweeping opinion, did its best to squelch any concerns about the legality of such municipal bonds. In Dubuque County $v$. Dubuque and Pacific Railroad, the court held that railroads were "roads" for the purposes of section 114, and that the constitution only prohibited the state, not counties or towns, from being corporate stockholders or incurring large debts. ${ }^{31}$ The case opened the floodgates for the deluge of Iowa bonds that followed. In 1855 , emboldened by the Dubuque County decision, Keokuk's leaders proposed to issue $\$ 600,000$ in bonds to aid three different railroad projects. Assured by town leaders that the bonds would pay for themselves, Keokuk voters approved the issuance of the bonds "with great unanimity."

Although a direct eastern connection was the most coveted of the projected railroads, most city planners believed that the best way to lure the capital needed to construct a major eastern trunk line was to complete the railroad that would follow the Des Moines River to the west. That line would ensure Keokuk's status as depot for the agricultural products of the fertile river valley. As a result, $\$ 400,000$ of the $\$ 600,000$ in bonds was earmarked for the western spoke, the Keokuk, Fort Des Moines and Minnesota Railroad. Miller was particularly enamored of this railroad. He invested enough of his own money in it to become an important shareholder and serve on its board of directors. ${ }^{33}$

As the best-funded railroad project, the Keokuk, Fort Des Moines and Minnesota Railroad made the most progress. The

30. Dubuque County v. Dubuque and Pacific Railroad, 4 Greene 1, 13, 14 (1853).

31. Ibid., 1. One of the state supreme court justices, Judge John Kinney, was deeply troubled by the majority's decision and filed a vigorous and prescient dissent. In particular, he questioned the court's conclusion that "road" in section 114 included a railroad. Kinney's greatest concern was that railroad fever had distorted the judgment of Iowa's citizens, politicians, and courts. Ibid., 13, 16 (1853).

32. Inaugural Address of D. W. Kilbourne, Esq. (Keokuk, 1855).

33. Gate City, 15 April 1858, 11 June 1862; Clemens, City of Keokuk in 1856, 8, 9. 
line received monies from both Keokuk and Lee County. Once again, however, the Gate City faced stiff competition from Burlington. Each city now had a railroad plunging into the interior, and leaders in both towns believed that whoever's railroad went farthest first would claim the agricultural trade of the farmers along the line. The race was on to reach interior points such as Eddyville and Ottumwa. Unfortunately for Keokuk, Burlington's railroad was already affiliated with one of the great railroad lines of the West, the Chicago, Burlington \& Quincy. Armed with Chicago's capitalist muscle, Burlington's line extended westward at a rate Keokuk could never match, beating the Keokuk line to Eddyville and then to Ottumwa. Eventually its tentacles fanned out as far as Montana, Wyoming, and Colorado, while Keokuk's line remained relatively small and independent. Because the Keokuk line terminated at the Mississippi River, it continued to depend on the river as an outlet, while goods sent on the Burlington line could be unloaded and shipped on the river or could roll on to Chicago. ${ }^{34}$

Whether Keokuk's boosters recognized it or not, their city's losing struggle with Burlington was really part of the much larger economic competition between St. Louis and Chicago. Despite the grandiose hopes of Keokuk's boosters, St. Louis viewed Keokuk not as a rival, but as a "sister city," an ally in its competition with Chicago. St. Louis merchants cheered the progress of the Keokuk, Fort Des Moines and Minnesota Railroad, noting that with its completion "most of the produce that might be diverted to Chicago by railroad, will find its way by an easy process to Keokuk and this city .... and thereby secure to St. Louis a vast amount of business. ${ }^{\prime 35}$

Keokuk's ties to St. Louis meant that it was aligned with the loser in the larger economic competition between St. Louis and Chicago. In 1850 St. Louis's trading hinterland stretched from Wisconsin to the Ohio Valley and out to the western

34. Richard C. Overton, Burlington West: A Colonization History of the Burlington Railroad (Cambridge, MA, 1941), 164-85; Arthur M. Johnson and Barry E. Supple, Boston Capitalists and Western Railroads: A Study in the NineteenthCentury Railroad Investment Process (Cambridge, MA, 1967), 156-80, 223, 224; Gate City, 5 September 1859 and 13 January 1860.

35. St. Louis Democrat, 22 May 1860. 
frontier. By 1860, however, Chicago merchants had claimed much of that territory. ${ }^{36}$ St. Louis's loss did not bode well for Keokuk, which continued to serve primarily as a transshipment point for goods coming north from St. Louis or for farm products headed south to St. Louis markets. While its rival Burlington had a direct rail connection with the triumphant economic metropolis of the West, Keokuk remained wedded to the steamboat and a declining entrepôt.

Recognizing their loss of status to Burlington, the tone of Keokuk's boosters started to sound desperate. Despite its $\$ 600,000$ debt, Keokuk still did not have an eastern connection, and Burlington's line was outdistancing its western road. Politicians asked the town to go even deeper into debt. "Although our city has subscribed liberally, she may yet have to do more," Mayor Samuel Curtis warned in 1856. "The county, city and individual effort will have to be strained to the utmost. . . . Such is the vital importance of Railroads to our success, that I present their interests as prior and paramount to all others. ... Upon the success of our roads,- - upon their progress this year, -will depend the future prosperity or adversity of our city. ... I am convinced that upon this year's success hang such fearful issues that I present it as a crisis in our history." As the Gate City concluded, Keokuk needed an eastern connection "or else ... must remain indefinitely as it is now, especially in the winter, a by-corner of the world. ${ }^{137}$

UNFORTUNATELY, Keokuk's boosters' obsession with railroads missed one crucial point. The railroad connections they craved were part of an expanding system that would eventually undermine all of Iowa's river towns, including both Bur-

36. Adler, Yankee Merchants, 3, 155. Historians have offered various reasons for St. Louis's decline. For city leaders' "innate conservatism," see Wyatt Belcher, The Economic Rivalry between St. Louis and Chicago, 1850-1880 (New York, 1947), 15; and Carl Abbott, Boosters and Businessmen, 97, 98. For the advantages of Chicago's connection to New York City rather than New Orleans, see Cronon, Nature's Metropolis, 60, 62. For the effects of Missourians' proslavery actions in "Bleeding Kansas" on perceptions of northern capitalists and potential emigrants, see Adler, Yankee Merchants, 11, 123-36, 139-41, 144.

37. "Inaugural Address of Mayor Curtis," 12; Gate City, 13 January 1860. 
lington and Keokuk. Railroads aided a river town while the town remained a western or eastern terminus of a line or as long as goods had to be unloaded at the river and ferried across. But if railroad bridges ever crossed the Mississippi, goods and passengers could traverse the river and speed on to Chicago without ever having to stop at the river towns. ${ }^{38}$

Inevitably, the first railroad bridge was built. In 1856 the Mississippi and Missouri Rail Road built the Rock Island bridge, extending the Chicago \& Rock Island line to Davenport. The first bridge to cross the Mississippi, it represented a triumph of nineteenth-century engineering. But its potential economic impact is what made its completion truly momentous. With the bridge finished, goods and passengers no longer had to be unloaded from railroad cars on one side, ferried across the river, and then reloaded on the other side. Cargo could also now cross the river easily year round. The potential benefits of the bridge led many commentators to view it as the epitome of western progress. One Chicago newspaper called the bridge "the greatest feat of the nineteenth century." ${ }^{\prime 39}$

Not everyone welcomed the bridge so warmly. To St. Louis merchants it was a threatening example of Chicago's aggressive efforts to seize regional dominance. Steamboat men also cursed the bridge, which had been built on a stretch of the Mississippi that had long been notorious for its powerful crosscurrents and dangerous submerged rocks. Now those problems were magnified as the treacherous waters swirled around the stone piers. This new hazard jeopardized even slowmoving steamboats with cautious and experienced pilots. Insurance companies raised their rates for boats that had to travel under the bridge. Within a month after the first train rolled across the bridge, twenty steamboats slammed into its unfor-

38. Mahoney, River Towns, 241. Not until much later did commentators in Keokuk finally come to grips with that grim reality. "Railroads are great equalizers," observed the Gate City in 1863 , "by which we mean to say that much of the trade which in former years found its way to the banks of the Mississippi is now concentrated at the more important places on the railroad in the interior." Gate City, 26 May 1863.

39. The Chicago Democratic Press, quoted in Marquis W. Childs, Mighty Mississippi: Biography of a River (New Haven, CT, 1982), 95, 96. 


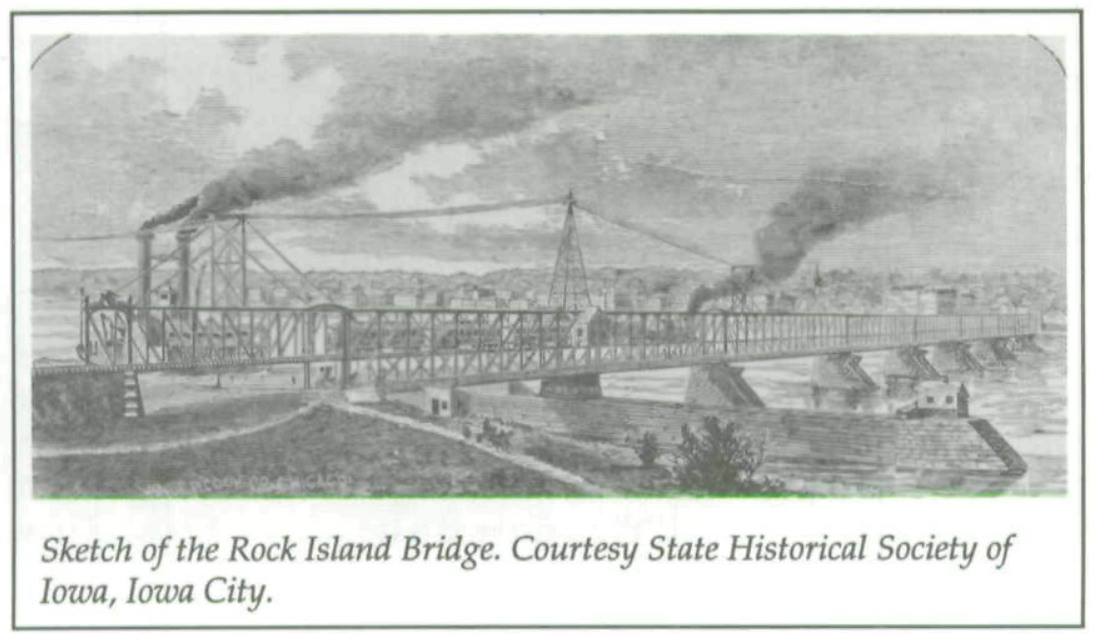

giving stone piers. One of those boats, the Effie Afton, exploded, bursting into giant flames that set the bridge itself on fire. Embittered steamboat men mourned the loss of the Effie Afton, but toasted the flames that scorched the hated bridge. The bridge, of course, was quickly repaired. ${ }^{40}$

For steamboat owners and pilots, the Rock Island bridge represented more than a simple hazard; it became a symbol of the railroads' devious attempts to create a transportation monopoly. ${ }^{41}$ As a result, lawsuits soon pitted the two great transportation technologies of the nineteenth century, steamboats and railroads, against one another. The outcome of those cases would shape the destiny of steamboat towns like Keokuk.

Steamboat owners launched their lawsuits against the Rock Island bridge in both Iowa and Illinois. In Illinois, the bridge company was sued by John Hurd, the captain of the Effie Afton. Hurd not only sought damages; he wanted the bridge declared a nuisance and torn down. The case of Hurd v. Railroad Bridge Company reached the United States Circuit Court in Chicago in September 1857. A young attorney named Abraham Lincoln

40. Benedict K. Zobrist, "Steamboat Men Versus Railroad Men: The First Bridging of the Mississippi River," Missouri Historical Review 59 (1965), 165; John C. Parish, "The First Mississippi Bridge," Palimpsest 3 (1922), 145; Childs, Mighty Mississippi, 99, 102.

41. Childs, Mighty Mississippi, 98. 
represented the Railroad Bridge Company. Cities and towns up and down the Mississippi followed the trial intently. Newspapers from St. Louis and New Orleans sent special correspondents to cover it. In the end, however, the Illinois case ended in a hung jury, and all eyes turned to the parallel case in Iowa. ${ }^{42}$

The Iowa case against the Rock Island bridge was brought in 1859 by James Ward, a part owner of four Mississippi steamboats, and captain of one of them. The bridge had not actually damaged Ward's boats, but he pointed to the many accidents that had already occurred to other boats as evidence that the bridge created an intolerable hazard to all steamboat traffic. Ward, like Hurd, wanted the bridge destroyed. As his attorney, Ward hired Samuel Freeman Miller. ${ }^{43}$

Miller's ties to the Gate City meant that he really had two clients in the case, Ward and the city of Keokuk. If Miller won, Keokuk would benefit in several ways. First, if the court placed the needs of steamboats over the needs of railroads, the case could protect the vitality of the riverboat trade on which Keokuk's economy still relied. Second, if the court ordered the bridge removed, all other plans to build bridges across the Mississippi (and there were many) would be placed in jeopardy, which would help ensure that river towns such as Keokuk would continue to function as indispensable loading and unloading points for goods that needed to cross the river. At the very least, a verdict in Ward's favor could buy Keokuk time. Even if Miller were able only to stop this one particularly dangerous bridge, the case might enable Keokuk to catch up with Iowa's pro-railroad river towns farther north. Perhaps by the time one of those towns could build a bridge, Keokuk could secure an eastern rail connection and maybe even a bridge of its own. If, on the other hand, the court gave rail-

42. Ibid., 100; Zobrist, "Steamboat Men Versus Railroad Men," 166-68; Parish, "The First Mississippi Bridge," 137; "Lincoln and the Bridge Case," Palimpsest 3 (1922), 142-54.

43. On the relative importance of steamboats and railroads to the nineteenthcentury economy, see George Rogers Taylor, The Transportation Revolution (New York, 1951). The case Miller made for the steamboats is described in the U.S. Supreme Court's decision on the issue: The Mississippi and Missouri Railroad Company v. Ward, 67 U.S. (2 Black) 485 (1862). 
roads the legal upper hand, Keokuk would certainly suffer. Trade and travel would increasingly take place along an eastwest axis, rather than a north-south one. The river, moreover, would soon be clogged with dozens of similar bridges. Steamboat travel would slow to a crawl, while the unimpeded railroads steamed right along.

Miller brought Ward's case to the federal district court in Iowa. Getting the case into Iowa's federal court was a coup for Miller. ${ }^{44}$ In that venue he could count on a sympathetic hearing from District Court Judge James M. Love. Not only was Love a Keokuk citizen, he was the former law partner of Miller's current partner, John Rankin. In the trial, Judge Love lived up to Miller's expectations. He accepted Miller's assertion that justice demanded that the bridge be removed. Miller charged that the bridge had created a serious hazard for steamboats. The steamboats and their owners had been there first. The bridge threatened their livelihood, so, Miller reasoned, it needed to be destroyed. Love, fearing that if the Rock Island bridge were allowed to stand "we shall probably, in no great period of time, have railroad bridges upon the Mississippi River at every forty or fifty miles of its course," agreed and ordered that the bridge (at least on the Iowa side of the Mississippi) be torn down. In Keokuk, they cheered the decision. ${ }^{45}$

The railroad, of course, appealed. The case reached the United States Supreme Court in 1862. Had Miller still been a private attorney, he would have argued the case, but by then he was one of the Supreme Court's justices. Because of his previous role in the litigation, however, he had to excuse himself from the proceedings. And this time, the outcome did not please Ward or Keokuk. Justice Catron, speaking for the Court, overturned Judge Love's decision. Catron based his opinion on the fear that if Love's logic were followed, "no lawful bridge could be built across the Mississippi anywhere; nor

44. Because the Mississippi and Missouri Railroad (which owned the bridge) was an Iowa corporation and Ward resided in Missouri, the district court could claim diversity jurisdiction.

45. Mississippi and Missouri Railroad Company v. Ward, 67 U.S. (2 Black) 485, 486 (1862); Gate City, 22 March 1860 and 6 February 1863; Parish, "The First Mississippi Bridge," 139. 
could the great facilities to commerce, accomplished by the invention of railroads, be made available where great rivers had to be crossed." Catron spoke for a Court stocked with former railroad attorneys who were less influenced by Keokuk's regional preference for steamboats than Judge Love had been. The bridge was allowed to stand, and the case opened the door for other bridges to be built. ${ }^{46}$ But by the time the case was decided in 1862, few in Keokuk even noticed. By then, Keokuk had other problems that dwarfed the threat posed by the Rock Island bridge.

IN 1857 an economic calamity struck Keokuk from which it would never recover. As 1857 began, a sagging market in Europe for produce from the American West had raised fears among eastern bankers and investors that they might be sitting on a speculative bubble about to burst. Newly cautious eastern banks stopped extending loans to western enterprises. Some refused to accept western currencies. Financial contraction and conservative decision making became the rule; the wild speculation, growth, and expansion of the early $1850 \mathrm{~s}$ abruptly halted. In the spring of 1857 , commercial credit dried up, forcing the already debt-ridden merchants of the West to curtail new purchases of inventory. Dwindling orders threatened New York wholesalers, thousands of smaller retail merchants across the country, and the railroads that linked them. The railroad age had created an interdependent national economy, and now an economic downturn in the West threatened to push the entire nation into an economic crisis. ${ }^{47}$

46. Mississippi and Missouri Railroad Company v. Ward, 67 U.S. (2 Black) 485, 496 (1862); Gate City, 22 March 1860 and 6 February 1863.

47. Mahoney, River Towns, 203; Abbott, Boosters and Businessmen, 17; Gate City, 30 May and 10 June 1857. Historians have disagreed over the exact causes of the Panic of 1857. Compare George W. Van Vleck, The Panic of 1857: An Analytical Study (New York, 1943), 53-58; Albert Fishlow, American Railroads and the Transformation of the American Economy (Cambridge, MA, 1965), 114-15; and James L. Huston, The Panic of 1857 and the Coming of the Civil War (Baton Rouge, LA, 1987), 5, 32, 34; with Peter Temin, "The Panic of 1857," Intermountain Economic Review 6 (1975), 1-12; and Fritz Redlich, The Molding of American Banking: Men and Ideas, 2 vols. in one (1951; reprint, New York, 1968), 2:1-3. 
As the financial panic hit with a vengeance in the late summer and fall of 1857, it soon became clear that Keokuk would not be spared. Farm prices crashed. Wheat that had garnered $\$ 2.19$ per bushel in 1855 fell to 80 cents per bushel by 1858 , with other crop prices suffering similar fates. Farmers' buying power evaporated as credit dried up. Merchants who had thrived during the boom years in a system based on credit and debt now paid the price for their risk taking. The Keokuk newspapers filled with advertisements from frantic merchants hoping to sell their inventories at almost any discount. "We think we have touched bottom," wrote one Keokuk observer in the fall of 1857, "and feel that any change must be for the better." Unfortunately for Keokuk, the next two years were even worse. ${ }^{48}$

While most Gate City residents suffered, lawyers thrived. Business failures, broken contracts, and hard times meant lawsuits. By 1859, two thousand cases crowded the docket of Lee County's district court. Men who heretofore had been land speculators, land agents, and merchants now rushed through half-baked legal apprenticeships and opened law offices. Keokuk's bar was so "crowded with attorneys," complained one observer, that "a stranger might have inferred that our citizens had all turned their attention to the law." Samuel Clemens's brother, Orion, was typical of this group. In the years preceding the panic, Orion's printing office published a city directory that boosters used to promote the town. After the panic hit, he sold his printing press and became a lawyer specializing in debt collection. ${ }^{49}$

For Samuel Miller and John Rankin the "hard, selfish times" did mean an increase in certain types of cases. Rankin had long held a reputation as the premier collections attorney in town. Now both Rankin and Miller were flush with such cases. On any given day in the late 1850 s, their firm ran dozens of legal notices in Keokuk newspapers notifying debtors and

48. Gate City, 3 September, 6, 9, 17, 27, and 30 October, and 14 November 1857 and 4 March 1858; Mahoney, River Towns, 235; Huston, The Panic of 1857, 13, 14, 18, 22, 29; R. M. Reynolds to C. Throop, 9 September 1857, R. M. Reynolds Collection.

49. Gate City, 9 February and 20 December 1859. 
other creditors of the firm's claims against them. ${ }^{50}$ They also served as trustees for defaulted parties and presided over the auctions of debtors' property. ${ }^{51}$ But overall, the economic collapse hurt Rankin and Miller. With little money available, few debtors could ever pay. Their firm's thriving land business dried up as land speculation ceased. And Miller, with his many personal real estate investments, had as much to lose in the town's demise as anyone in Keokuk. The sheer scale of the catastrophe that had hit Keokuk left Miller dumbfounded and grasping for answers as to how things could have turned sour so quickly. "No one," Miller lamented in 1858, "anticipated the calamity which has overwhelmed the community." ${ }^{\prime 2}$

Many critics believed that Keokuk's economic crisis was being exacerbated by the thousands of lawsuits then under way. Keokuk businessmen and landowners needed to "quit suing each other, cease mourning over the great collapse and awful shrinkage," and get on with things, complained a typical letter to the editor. ${ }^{53}$ Even though he earned his livelihood from such lawsuits, Miller agreed, so in 1858 he proposed a special rule requiring that anyone who brought a frivolous lawsuit be fined by the district court. The overburdened judges of the district court welcomed and adopted Miller's rule. ${ }^{54}$

In 1858 and 1859, Keokuk's economic situation deteriorated further. Two years of successive crop failures in the surrounding countryside were compounded by two brutal winters that killed cattle across Iowa. ${ }^{55}$ As the depression wore on, Keokuk began to take on a ghostly aspect. With few customers, the

50. On February 15, 1859, for example, Rankin, Miller, and their new partner Enster ran twenty-seven legal notices in the Gate City. Rankin's reputation as a first-rate collections attorney is described in his profile in the Caleb Forbes Davis Collection, reel 2, book 5, p. 259. The "hard, selfish times" quote is taken from the Gate City, 17 November 1857.

51. Gate City, 20 July 1860.

52. Samuel Miller, Letter to the Editor, Gate City, 17 September 1858.

53. Gate City, 8 September 1858.

54. Gate City, 17 September 1858.

55. Abbott, Boosters and Businessmen, 17; Gate City, 10 and 12 July 1858; Mildred Throne, "'Book Farming' in Iowa, 1840-1870," Iowa Journal of History 49 (1951), 121. 


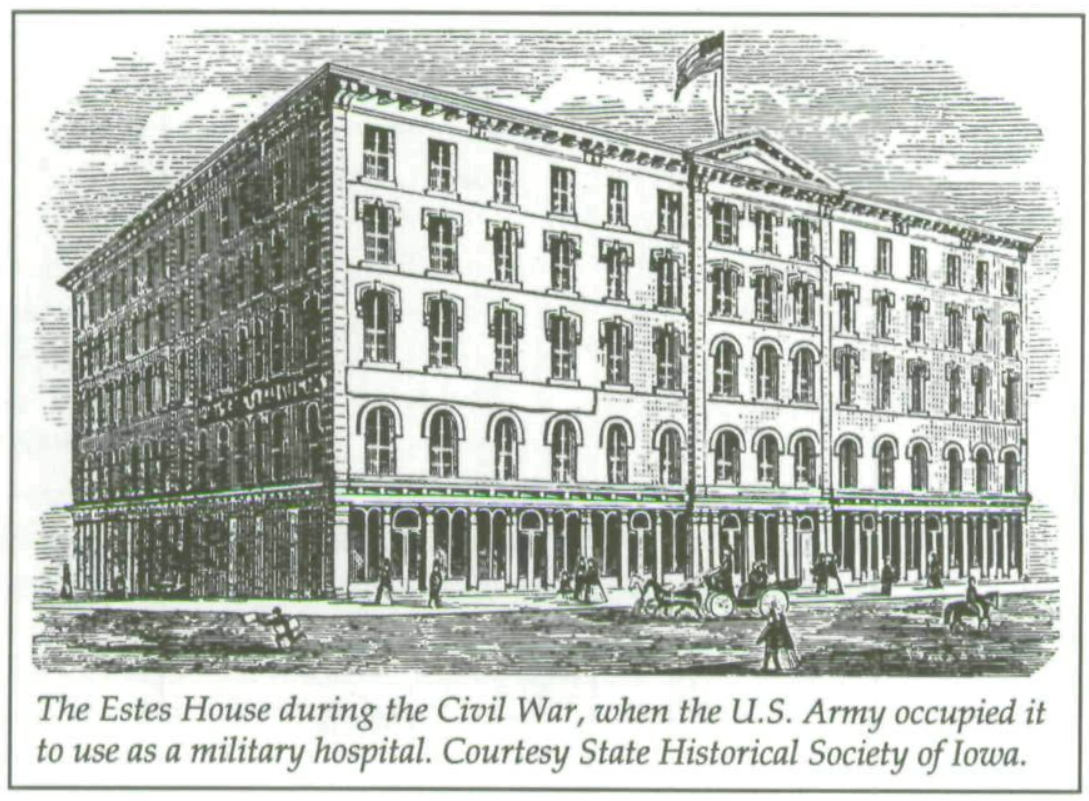

town's gas works stood "silent and gloomy" at the end of Main Street. Once busy streets were abandoned as businesses failed. In November 1859, the last merchant closed his doors on Keokuk's once bustling Second Street. "Alas, for Second Street," cried an editor. "Once so grand with its Athenaeum, its Bank, its Auction Stores, Bookstores and crowds of eager speculators! Now so deserted, so quiet!" In the center of town, the Estes House, which was to have been the Gate City's "grand hotel," sat unfinished, unfurnished, and unoccupied. A visiting reporter dubbed the roofless hotel "a monument of the folly to which even wise men will be led in a time of general prosperity." In a particularly emblematic move in the frigid December of 1858, the town, unable to pay the gas bill, had shut off Keokuk's street lamps. The lampposts would stand unused for years, looming in the darkness, spectral reminders of better times. ${ }^{56}$

The days when hundreds of wagons from the countryside clogged Keokuk's streets were gone. Railroads had siphoned off some of the business. The economic collapse scared off much

56. Gate City, 18 June and 29 December 1858, 26 October and 23 November 1859, and 12 February 1864; Davenport Gazette, 17 May 1859. 
of the rest. "This is the deadest, dullest, most quiet place I ever beheld or heard of," wrote a visiting reporter from the Chicago Tribune. ${ }^{57}$ The reporter may have exaggerated, but he did correctly present a cold truth about Keokuk. The boom had ended.

Damaging reports soon circulated in the East that Keokuk had been hit worse by the financial panic than other Mississippi River towns. One article compared Keokuk to the "doomed city of Jerusalem." Keokuk, it said, had "creditors without and creditors within. ... Every third man is a lawyer ... . every other man virtually a pauper, and all standing in listless and unprofitable idleness, except the police and constables. Three millions of dollars are to be sued for in the courts ... . and 'ruin and degradation' is given as the probable result. ${ }^{158}$ Reprinted in newspapers throughout the country, this article was particularly deleterious to Keokuk's reputation. "Every paper from Maine to Texas, and from Minnesota to Florida has given it [a] place," the Gate City said blackly, "and we are waiting anxiously for the next steamer, expecting to see it in the London Times." The notoriety had a deadly effect. After the story ran in Baltimore, New York, and Philadelphia papers, Keokuk merchants and their purchasing agents found themselves blacklisted in those cities. Many eastern wholesalers canceled their Keokuk contracts. The town's name became synonymous with the financial reverses in the West. "Reports more injurious to Keokuk," concluded the Davenport Gazette, "have gone out than in relation to any other western city." ${ }^{159}$ In an age when eastern perceptions of western cities had a major impact on the flow of capital, a spate of negative publicity could destroy a boomtown in a flash. Keokuk's reputation after the Panic of 1857 may have been the worst of any town in the West. ${ }^{60}$

57. Chicago Tribune, 16 June 1858, quoted in the Gate City, 21 June 1858.

58. Article quoted in the Gate City, 8 October 1858.

59. Gate City, 8 and 26 October 1858; Davenport Gazette, 17 May 1859.

60. Adler, Yankee Merchants, 9, 43. See also John D. Haeger, "Capital Mobilization and the Urban Center," Mid-America 60 (1978), 88; idem, "Eastern Money and the Urban Frontier," Journal of the Illinois Historical Society 64 (1971), 267-84; and idem, "The Abandoned Townsite on the Midwestern Frontier," Journal of the Early Republic 3 (1983), 165-83. 
A HUGE MUNICIPAL DEBT magnified Keokuk's problems. By 1858 , Keokuk owed $\$ 900,000$, mostly on railroad bonds, while the value of its taxable property dropped by $\$ 5.5$ million between 1857 and 1858. Lots that had brought a thousand dollars before the crash now could not be sold for ten dollars. Hard-hit property owners were unable to pay their taxes, and thousands of properties slipped into tax delinquency. On June 7, 1858 , alone, Lee County put up for auction more than a thousand lots with unpaid taxes. Keokuk's Union Hotel, bought by an investor in 1856 for $\$ 28,000$, sold at a tax auction in 1857 for $\$ 2,800$. Deeply in debt, with tax revenues slowed to a trickle, the town cut back drastically on services. Streets and sidewalks deteriorated into a "condition of decadence." City police went unpaid and morale sank. A crime wave struck the town. Thieves robbed private homes and merchants' safes. The levee, once the pride of Keokuk, became a haven for violence and thievery. Pickpockets plagued the packet depot, and unemployed laborers filled the saloons. Gangs of Irish longshoremen attacked rivals who tried to claim dwindling work. ${ }^{6}$

Boosters and civic leaders desperately searched for solutions to Keokuk's problems. One drastic proposal suggested that in order to lure capital back to Keokuk "it would undoubtedly be good policy for real estate holders to give away every other lot, if necessary." Some suggested that Keokuk build giant grain elevators modeled on those in Chicago. "Where men sell their grain they also buy their goods," went the argument. Others proposed that Keokuk start a hydraulic company to harness the Mississippi's rapids and to use the energy thus generated to power factories. In June 1858 Samuel Miller attended a meeting convened to discuss that plan. The sparsely attended gathering quickly descended into ineffectual bickering after Mayor H. W. Sample shouted that southern Iowa "is not a manufacturing country and never could be." ${ }^{162}$

While boosters offered various solutions to the city's troubles, most citizens blamed Keokuk's torpid economic recovery

61. Gate City, 7 June 1858, 15 April, 2 June, 19 September, and 8, 12, and 18 November 1859, 8 March, 2 and 31 October, and 6 December 1860, and 21 March 1861; History of Keokuk: 1820 to 1906 (Keokuk, 1906), 8, 42.

62. Gate City, 7 July 1859, 22 September 1860, and 29 June 1858. 
on its debt from railroad bonds. Yes, Keokuk had received some benefits from those bonds. By 1858, the Keokuk, Fort Des Moines and Minnesota Railroad had 38 miles of track heading west, and the Keokuk, Mt. Pleasant \& Muscatine line ran twelve miles north, but construction had progressed slowly, and there was still no eastern connection. The railroads had done little to pull Keokuk's economy back from the brink. Instead, the city's railroad bond debt had destroyed its credit. Keokuk still had the "natural advantages" its boosters had long trumpeted, but no capitalist would touch a small city saddled with such a huge debt. Keokuk's leaders recognized the problem the bond debt posed. "A crisis has come," Mayor Sample admitted. "The arm of industry is paralyzed, property and business are depressed $\ldots$ and we find our city encumbered with a large indebtedness. ... We cannot carry such a load and prosper." ${ }^{\prime 3}$

By 1859, Keokuk's leaders admitted that they could not pay the interest on the city's bonds. The city defaulted, a catastrophic blow to its reputation. Outraged bondholders charged Keokuk with open repudiation and demanded that its citizens be taxed until their debts were honored. When monied men pilloried Keokuk's name in the East, Keokuk's leaders offered this simple, but painful, response: "We can't pay now; we doubt if we can ever pay if the full amount is insisted upon." Civic leaders held out hope that the debt could be renegotiated. With the debt "settled on some honorable basis . . Keokuk would arouse from her lethargy 'like a giant refreshed with wine.'" Toward that end, in the winter of 1859, Mayor Sample traveled to New York City to try to reach a compromise with bondholders. The trip proved spectacularly unsuccessful. Rumors even circulated that angry Wall Street creditors had had the mayor thrown in jail for swindling. ${ }^{64}$

Although few had complained back when the railroad bonds had been issued, many Keokuk taxpayers now claimed that they had never approved of the various railroad schemes.

63. "Inaugural Address of H. W. Sample," reprinted in the Gate City, 16 April 1858; Mahoney, River Towns, 240. See also "Statement of City Council," in Gate City, 8 July 1858, which agreed that "our greatest error was in contracting an enormous debt to aid in the construction of railroads."

64. Gate City, 29 January, 14 April, and 15 February 1859. 
With boom turned to bust, angry voices called into question the constitutional validity of the bonds, even though the Iowa supreme court had declared them constitutional in $1853 .{ }^{65}$ Lo$\mathrm{cal}$ attorneys launched new legal challenges to the bonds, but in the 1857 case, Clapp v. County of Cedar, Iowa's supreme court justices again said that it was far too late to turn back. Whatever doubts they may have "tacitly entertained" about the bonds, it was now "impossible to recede." "To change now," Judge Woodward wrote, "would be the worst form of repudiation, judicial repudiation." The court pointed to the impact such a decision would have on people who had innocently bought Iowa's railroad bonds. Besides, Iowa cities had benefited from the bonds. Perhaps some railroads were not completed, but some had made progress. "Our people," an exasperated Woodward added, "have received the consideration of these bonds." ${ }^{\prime 66}$

By admitting that they "tacitly entertained" some doubts about the bonds' original validity, the justices inadvertently encouraged further challenges. Desperate Iowans clung to the thinnest of straws. Encouragement could also be found in Chief Justice Wright's dissenting opinion, in which he said he believed that the bonds could still be declared void. The citizens of Keokuk and Lee County rallied around the chief justice's dissent. The slightest hope of somehow escaping their debilitating debts was all they needed to keep launching legal assaults on the railroad bonds. Given Keokuk's desperate situation, it is not surprising that these legal challenges continued.

65. Even during the boom years, a small cadre of opponents to the bonds had emerged. In 1856 twelve residents had launched an unsuccessful suit to prevent Lee County from issuing railroad bonds (McMillan v. Lee County and Boyles, 3 Iowa 311 [1856]). The plaintiffs argued that the vote to approve the bonds had lumped three different railroad projects together in an unconstitutional way. The Iowa supreme court agreed, and the bonds were delayed. The Iowa legislature subsequently cured this defect by legalizing "aggregate" votes in which three bond issues were lumped together. Thus when the case returned to the Iowa supreme court a second time in 1858, the court said that the issue had been definitely settled in favor of the validity of the bonds (McMillan v. Boyles, County Judge, 6 Iowa 304 [1858]).

66. Dubuque and Pacific Railroad v. Dubuque County, 4 Green 1 (1854); McMillan v. Boyles, County Judge, 6 Iowa 304 (1858); Clapp v. County of Cedar, 5 Iowa 15 (1857). 
What is surprising is the name of the lawyer who became the anti-bond champion: Samuel Freeman Miller.

SAMUEL MILLER made an unlikely anti-bond warrior. He had, after all, served on the board of, and held shares in, a Keokuk railroad that had benefited from the bonds. He also had made a number of other speculative investments in land and businesses along the routes of projected railroads. Moreover, a large portion of his legal career in the 1850s had been devoted to cases he described as "suits to collect just debts." ${ }^{167}$ One might assume that Miller, the collections lawyer, speculator, and investor, would have sided with bond purchasers over those who were trying to escape their debts. Not so.

Beginning in 1859, Miller handled a number of cases that challenged the validity of the railroad bonds, challenges that relied on the same worn arguments about section 114 and debt limits. In Robert Moir v. Jefferson County, Miller defended an Iowa county that had defaulted on its payment to bondholders. Miller argued that the county officials who had authorized the bonds had no constitutional authority to do so because "any roads" under section 114 did not include railroads. Consequently, the bonds were void, and current county officials should not be bound by the irresponsible actions of their predecessors. The district court judge in the case was once again Keokuk's James M. Love, someone potentially sympathetic to Miller's claim. In this case, however, local sympathies did not carry the day. ${ }^{68}$

Judge Love rejected Miller's contentions in no uncertain terms. "Our counties have been, it must be admitted, involved in a great misfortune," Love recognized. However, he continued, "it is now proposed that we add to our misfortune the disgrace of repudiation." Worse yet, the judiciary would be sanctioning such repudiation, which, Love warned, "would lead to the distraction of all public credit." Love admitted that the counties' authority under section 114's "any road" provi-

67. Gate City, 17 September 1858.

68. Case of Robert Moir v. Jefferson County, described in detail in the Gate City, 14 April 1860. 
sion had been a stretch. But the benefit of the doubt in such cases should not go to a county that had already profited from the bonds. ${ }^{69}$ With Keokuk's own Judge Love siding against Miller and the county, all further legal efforts appeared futile.

Despite Judge Love's decision, however, many Keokuk and Lee County citizens vowed to keep up the fight. Thousands attended anti-railroad tax meetings where speakers encouraged citizens to resist paying their taxes. Lee County citizens, the protesters complained, were being asked to pay $\$ 108,000$ just in back interest. "We are utterly unable to pay the said tax, were we ever so willing," they contended, "and we are not willing." Speakers urged citizens to attend auctions of tax delinquent property and then refuse to bid. One resolution passed at the meeting warned, in a veiled threat of violence against tax collectors, "that while we expect all county officers to do their sworn duty, we have no respect for those persons who may voluntarily undertake to do the dirty work, and we will visit with our indignation all who may do so." Most of all, the protesters beseeched Miller and other attorneys to persist in the anti-bond fight and to "continue the litigation as long as there is any foothold for us to stand upon. ${ }^{\prime \prime 7}$

In the spring of 1861, with the Civil War looming, Miller was back in the courtroom challenging the validity of the railroad bonds. The case of Beecher v. City of Keokuk involved one particularly questionable bond issue. Keokuk had issued the thousand-dollar bond nine years earlier, not to fund a railroad, but to pay Mayor Sample's expenses for a trip to Congress to lobby for railroad appropriations. If ever a case existed where the anti-bond forces could carry the day, this would be it. Because the bond's owner lived in Ohio, and therefore there was diversity of citizenship, the case went to Judge Love's federal district court. At the trial, Miller convincingly argued that the city had never had any authority to issue bonds for such overly broad purposes. In this case, Judge Love agreed and

69. Ibid. In determining against the county, Love relied on Piqua Branch Bank v. Knoop, 54 U.S. (16 Howard) 376 (1853).

70. "Report of the Anti-Railroad Tax Meeting" of 16 April 1860, reprinted in the Gate City, 19 April 1860; "Report of Anti-Railroad Tax Mass Meeting" of 6 October 1860, reprinted in the Gate City, 13 October 1860. 
gave Miller a rare victory in a bond case. Both Love and Miller recognized, however, that the United States Supreme Court would ultimately have to resolve the issue. Miller, in fact, had already secured admission to practice before that Court in hopes that he could argue the issue there. By the time the case had made its way to the Supreme Court, however, Miller had been appointed to the High Court. So, instead of arguing before the Court as a lawyer, Miller found himself judging nearly fifty such municipal bond cases from the bench. In a majority of those cases, Miller would be a lone dissenting voice on a Court that consistently upheld the interests of bondholders. ${ }^{71}$

HOW DOES ONE EXPLAIN Miller's dramatic transformation from the role of speculator and railroad investor into that of anti-railroad bond crusader? Certainly, Miller's own financial self-interest played a role. If Keokuk remained mired in debt, the city would not grow and Miller's many speculative real estate holdings would never increase in value. Miller recognized this. In 1868, while he was serving on the United States Supreme Court, Keokuk leaders asked him to help in a new effort to renegotiate the city's debt with the bondholders. Miller agreed to help, knowing full well that if he succeeded he would not only confer "an immense benefit on my neighbors and fellow citizens," but would also add "largely to the value of my own property. ${ }^{\prime \prime 2}$ Yet to say simply that Miller's actions were due solely to his own property interests ignores the authentic ideological and moral transformation that influenced many Iowans in the late 1850s.

Miller's transformation was not unique. Like Miller, Iowa's Republican Party in the mid-1850s had welcomed railroads and the men who promoted them. The railroads brought Iowa's Republican farmers higher prices for their corn and hogs and an unprecedented selection of goods to buy. River town Republicans welcomed railroads because they feared that if they

71. Miller to William Pitt Ballinger, 11 November 1860, folder 1, box 1, Miller Papers.

72. Miller to William Pitt Ballinger, 27 August 1868, Ballinger Collection. 
did not secure them, a competing town would. For a time, promoters and eastern investors had seemed to be public benefactors. Town boosters courted the attention of eastern capitalists with money to invest, and Republican leaders fawned over them. Indeed, many of Iowa's most prominent Republican leaders themselves became promoters and investors. James Grimes, Samuel Curtis, James Harlan, and Josiah Grinnell all had ties to railroad companies. In this regard, Miller was hardly alone. As the 1850 s progressed, however, the euphoria wore off. Republicans soured on the venal ways of eastern railroad promoters and the power they held over Iowa's towns and cities. Furthermore, after spending millions of dollars, Iowa's taxpayers failed to see corresponding benefits. By 1862, Iowa towns and counties had invested an estimated seven to twelve million dollars in railroad bonds, yet they had only 731 miles of rail-most of them poorly constructed-to show for it. ${ }^{73}$

It was not simply that Iowans felt cheated. Republicans in Iowa increasingly viewed eastern capitalists and bondholders through the lens of a maturing free labor ideology. The chief villains for the Republicans remained southern planters, not eastern capitalists, but by the end of the decade, Republicans had come to view the bondholders and planters as cut from the same cloth. Both were aristocratic economic parasites who lived off the labor of the producing classes. Iowans bridled at the practices of the New York bond market, where investors bought western railroad bonds at steep discounts (often 25 to 35 percent below face value). While eastern speculators sat in leather chairs in their Gramercy Park mansions gambling on discounted bonds, Iowa farmers and merchants broke the soil, stocked the shelves, unloaded the carts, and labored from dawn to dusk. It is the "toiling millions," said a Keokuk Republican, "who conquer all obstacles, provide all the necessaries and luxuries of life, and make all the real wealth of the land." Now,

73. David S. Sparks, "Iowa Republicans and the Railroads, 1856-1860," Iowa Journal of History 53 (1955), 274-76, 283; idem, "The Decline of the Democratic Party in Iowa, 1850-1860," ibid., 13; Earl S. Beard, "Local Aid to Railroads in Iowa," ibid. 50 (1952), 15-16. 
in the midst of hard times, with few railroads completed, the indolent bondholders demanded their pound of flesh. ${ }^{74}$

During the years that Iowa Republicans turned against the bondholders, Samuel Miller took a more active role in the party. $\mathrm{He}$ had participated in party activities at the local level ever since the party's founding in 1856. He attended meetings, rallies, and picnics and gave an occasional speech. By the end of the decade, he had been elected chairman of the Republican Committee of Lee County and held a seat on the Republican State Executive Committee. In addition, Republican groups all across Iowa sought him out to speak to the party faithful. Throughout 1858, 1859, and 1860, he barnstormed the state, speaking to crowds in Farmington, Montrose, West Point, Keosauqua, and Fort Madison. In 1860 a Republican meeting in Primrose that featured Miller and his partner John Rankin as speakers drew six thousand people. In each speech Miller spoke "with great force and eloquence upon the free and glorious principles of Republicanism"; he damned the slaveholders, the bondholders, and the Democrats. On October 10, 1860, on the eve of the presidential election, Republicans held a grand mass meeting in Keokuk. More than twenty-five thousand party faithful poured into town from all over southeastern Iowa and northeastern Missouri. Two thousand torchbearers joined the parade of the Republican Wide-Awakes. And Miller, naturally, served as master of ceremonies. ${ }^{75}$

74. Beard, "Local Aid to Railroads," 15-16; Eric Foner, Free Soil, Free Labor, Free Men: The Ideology of the Republican Party before the Civil War (New York, 1970); John Lauritz Larson, Bonds of Enterprise: John Murray Forbes and Western Development in America's Railway Age (Cambridge, MA, 1984), 79, 81, 90; Gate City, 24 May 1860. See also Alan Jones, "Republicanism, Railroads, and Nineteenth-Century Midwestern Constitutionalism," in Ellen Paul and Howard Dickman, eds., Liberty, Property, and Government: Constitutional Interpretation before the New Deal (Albany, NY, 1989), 239-65. For the view that the shift of Republican Party leaders on the issue of railroad bonds was less ideological and more cynical, see Robert Cook, Baptism of Fire: The Republican Party in Iowa, 1838-1879 (Ames, 1994), 115.

75. Gate City, 27 and 28 September and 1 October 1859, 20 March, 4 June, 14 July, 23, 28, and 30 August, 11 September, and 11 October 1860; Floyd and Marion Rinhart, "'The Prairies A-Blaze': Iowa Wide Awakes Carry Torches for Lincoln," Iowa Heritage Illustrated 77 (1996), 46. 


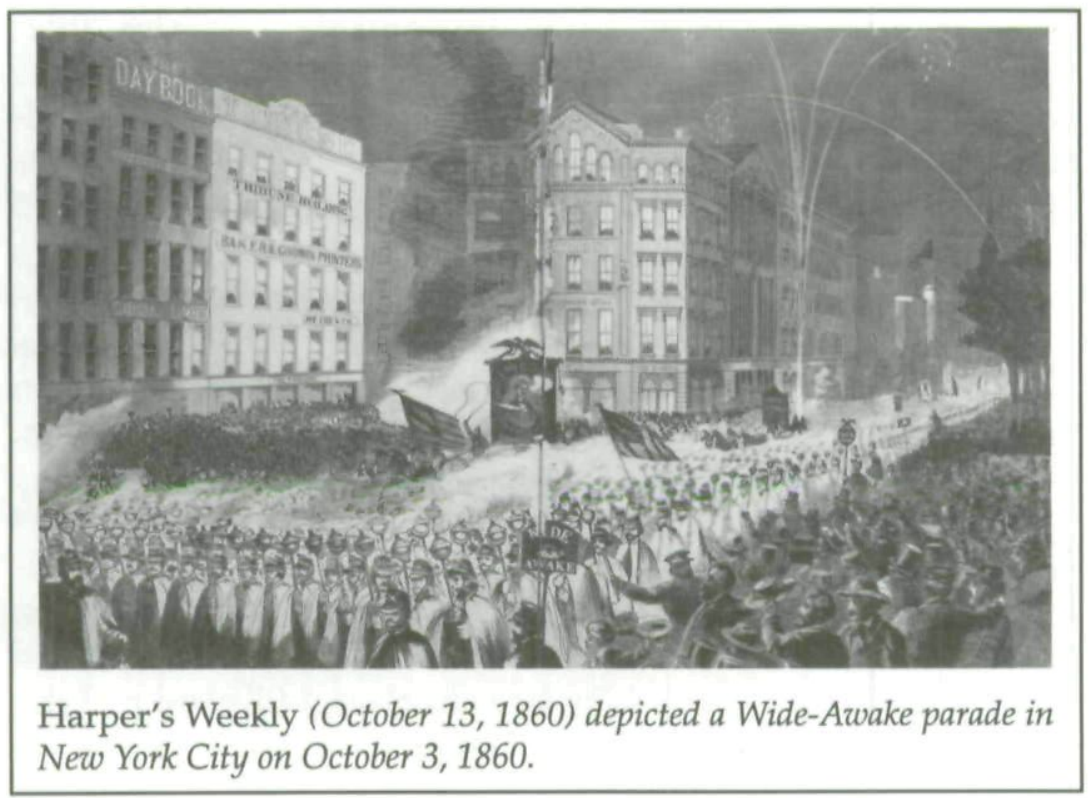

Because Miller's public standing undoubtedly benefited from his anti-bond efforts, it might appear that he challenged the bonds and bondholders merely to further his political career and protect his property interests. To be sure, by 1859 his role in the bond cases had made him widely popular just as Republicans were seeking candidates who were not associated with the railroads. Although he had twice lost bids for minor offices earlier in the decade, Miller now became a serious statewide political force. In 1862 he launched an ultimately unsuccessful bid to unseat incumbent Republican governor Samuel J. Kirkwood. Although he lost, his higher profile subsequently helped him secure his nomination to the United States Supreme Court in July $1862 .^{76}$

Certainly Miller's desire for office played some role in his taking up the anti-bondholder banner, but more important in-

76. James Grimes to Samuel Kirkwood, 24 April 1859, Samuel J. Kirkwood Papers, State Historical Society of Iowa, Des Moines; Gate City, 3 and 5 August 1861. The strong support Miller's bid for a Supreme Court nomination received from the congressional delegations of Wisconsin, Kansas, and Minnesota suggests a degree of regional popularity. 
fluences than raw political ambition were at work. The larger economic and political lessons Miller had learned in Barbourville and Keokuk converted this prosperous, prominent moderate into a powerful advocate for the repudiation of debts. Twice he had moved to prosperous trading towns, established himself, and built a life, only to have the bottom drop out from under him. In Barbourville his dreams fell victim to the steamboat. In Keokuk it was the railroad. Miller and many others had invested their skill, energy, and money in an Iowa town that seemed to have all the earmarks of future prosperity. Then, through no fault of their own, their dreams had been shattered.

In the railroad bond cases that came before the United States Supreme Court, Miller spoke for the multitudes of talented men and women who had moved to frontier towns, worked hard, and played by the rules, only to be crushed by forces outside their control. In case after case Miller pinned the blame for economic failure on eastern bondholders, and he repeatedly charged that his judicial brethren on the Court bent over backwards to defend the bondholders' interests. Unfortunately for Keokuk and other debt-ridden towns, Miller's was usually a lone voice of dissent. In fact, he dissented more frequently in municipal bond cases than in any other. In the forty-nine cases involving municipal bonds decided during his tenure on the Court, he dissented thirty-one times. ${ }^{7}$

In the municipal bond cases, Miller's hatred for the bondholders shaped his judicial views. He expressed little sympathy for "a gambling stockbroker of Wall Street" who buys discounted bonds of questionable constitutionality. He described the bondholders and capitalists in conspiratorial terms, calling

77. Some of his more notable dissents include Olcott $v$. The Supervisors, 83 U.S. (16 Wallace) 678 (1873); Pine Grove Township v. Talcott, 86 U.S. (19 Wallace) 666 (1874); Riggs v. Johnson County, 73 U.S. (6 Wallace) 166 (1868); Butz v. Muscatine, 75 U.S. (8 Wallace) 575 (1869); Marsh v. Fulton County, 77 U.S. (10 Wallace) 676 (1871); Mercer County v. Hackett, 68 U.S. (1 Wallace) 83 (1864); Meyer v. Muscatine, 68 U.S. (1 Wallace) 384 (1864); Rogers v. Burlington, 70 U.S. (3 Wallace) 654 (1866); Lynde v. Winnebago, 83 U.S. (16 Wallace) 6 (1873); Humboldt Township v. Long, 92 U.S. 642 (1876); Nugent v. The Supervisors, 86 U.S. (19 Wallace) 241 (1874); United States v. County of Clark, 96 U.S. 211 (1878). On a few occasions Miller was able to carry the day in a municipal bond case. See Nashville v. Ray, 86 U.S. (19 Wallace) 468 (1874); Buchanan v. Litchfield, 102 U.S. 278 (1880); Litchfield v. Ballou, 114 U.S. 190 (1885). 
them a "keensighted well organized class." He blamed the West's economic problems on "the united, vigorous, and selfish efforts of the capitalists- the class of men who as a distinct class are but recently known in this country-I mean those who live solely by interest and dividends. ... They engage in no commerce, no trade, no manufactures, no agriculture. They produce nothing." Their "only object in life," Miller wrote bitterly in 1878, seems to be to "have their golden egg, shell meat and all, though they destroy the goose from which they know it must come if it come at all." As long as they crippled western manufacturers, merchants, farmers, and towns with their exorbitant demands, Miller sighed, "it is hard to see when prosperity will return." In his private correspondence, he scathingly accused "the Bond-holding class" of "subverting the gov't to their purposes." "It is the most painful matter concerned with my judicial life," Miller wrote of the bond cases, "that I am compelled to take part in a farce whose result is invariably the same, namely to give more to those who have already, and to take away from those who have little, the little that they have. ${ }^{\prime 78}$

As a result of the bond cases, Miller came to believe that the Court on which he sat had become a tool of a few disproportionately powerful investment capitalists. If a case that involved their interests reached the Court, the result was predetermined. The railroad bond cases proved the point. "Our Court or a majority of it," Miller complained, "are, if not monomaniacs, as much bigots and fanatics on that subject as is the most unhesitating Mahemodan [sic] in regard to his religion." ${ }^{\prime 79}$

78. Miller to William Pitt Ballinger, 28 April 1878 and 13 January 1877, Ballinger Collection; Gelpcke v. Dubuque, at 214; summary of a letter from Miller in William Pitt Ballinger's Diary, 5 May 1878, Ballinger Collection.

79. Miller to William Pitt Ballinger, 17 June 1869 and 13 January 1878, Ballinger Collection. Miller, of course, could stake equally extreme positions in his defense of debtors. In two cases heard by the Court, two governments (one city and one state) that had issued bonds subsequently declared a tax on the interest they were obligated to pay on those bonds. Consequently, while they owed 6 percent interest, they paid only 4 percent, declaring a 2 percent tax. Miller, in lonely dissents, supported this practice. But as Stephen J. Field pointed out in the majority opinion in Hartman v. Greenhow, "If, against the express terms of the contract, the state can take a portion of the interest in the shape of a tax on the bond, it may at its pleasure take the whole." Hartman v. Greenhow, 102 U.S. 672, 685 (1881); Murray v. Charleston, 96 U.S. 432 (1878). 
Recognizing that Miller was "sympathetic to the taxburdened people of Iowa," Miller's biographer concluded that Miller "tended toward agrarian radicalism." ${ }^{180}$ But the "agrarian radical" label simply does not fit. In Barbourville, Miller supported Cassius Clay's ambitious plan to bring New Englandstyle mills and factories to the Kentucky mountains. He hoped that Barbourville would mushroom into a great city, and he left when it became clear that it would not. In Keokuk, he speculated in coal mines, railroads, and real estate, staking his fortune on the hope that the Gate City would become the next Chicago or St. Louis and that its success would build his own personal fortune. He certainly never advocated returning America to a pastoral landscape populated only by small towns and farms. Instead, his interests lay with the innumerable middle-class merchants, professionals, and small speculators clustered in myriad western towns and cities who expected to benefit from America's wondrous growth. When Keokuk's economy crashed, taking the dreams of that city's middle class down with it, Miller's optimism faded. No longer could he believe, as he had in his youth, that the American economic system did not unfairly favor the wealthy, that it guaranteed success to the talented and hard-working. In the end, he blamed the West's problems on a capitalist class that abused the government. He also decried the courts and the economic system for their own myopically selfish ends.

In October 1890, on the occasion of Miller's death, the editor of the Keokuk Gate City looked back on his city's early years and noted with awe the great pool of legal talent antebellum Keokuk had possessed. Pointing to men such as Miller, Belknap, Love, and Rankin, the editor tried to explain to his readers why so many talented lawyers had chosen to settle in Keokuk. Thirty years later, after all, Keokuk remained a small, littleknown, midwestern town with fewer than fifteen thousand residents. Why then did they choose such a place? "Just as a great company of strong young men go to any prosperous young territory not for what it is but because of what they hope it and they may be," wrote the editor of the Gate City, "so

80. Fairman, Mr. Justice Miller, 299. 
Keokuk drew to itself the youth and strength of young lawyers who came not to the population that was but to the hundreds of thousands that were expected. ${ }^{1 / 1}$ After the Panic of 1857, those dreams faded as the expected multitudes failed to arrive. Only the debts to the capitalists remained.

81. Gate City, 18 October 1890. 
Copyright of Annals of Iowa is the property of State of Iowa, by \& through the State Historical Society of Iowa and its content may not be copied or emailed to multiple sites or posted to a listserv without the copyright holder's express written permission. However, users may print, download, or email articles for individual use. 